\title{
Trophic Structure and Origin of Resources of Soil Macrofauna in the Salt Marsh of the Wadden Sea: A Stable Isotope $\left({ }^{15} \mathrm{~N},{ }^{13} \mathrm{C}\right)$ Study
}

\author{
Maria Rinke ( $\sim$ maria.rinke@uni-goettingen.de) \\ University of Göttingen \\ Philipp M. Bendisch \\ University of Göttingen \\ Mark Maraun \\ University of Göttingen \\ Stefan Scheu \\ University of Göttingen
}

\section{Research Article}

\section{Keywords:}

Posted Date: February 28th, 2022

DOI: https://doi.org/10.21203/rs.3.rs-1275741/v1

License: (c) (i) This work is licensed under a Creative Commons Attribution 4.0 International License. Read Full License 


\section{Abstract}

Salt marshes exist along the gradient of the marine mudflat to the terrestrial dunes, with a gradient of shore height and associated plant zonation. The lower salt marsh (LSM) extends from the mean high tidal level to $35 \mathrm{~cm}$ above that level and is followed by the upper salt marsh (USM). Despite changes in the amount of allochthonous marine input and in abiotic conditions, little is known about changes in the trophic structure and used of basal resources by the soil macrofauna along marine terrestrial boundaries. Natural variations in carbon stable isotope ratios $\left(\delta^{13} \mathrm{C}\right.$ signatures) allow insight into basal resources of consumers such as marine algae, terrestrial C3 and C4 photosynthesising plants. Furthermore, variations in nitrogen stable isotope ratios ( $\left({ }^{15} \mathrm{~N}\right.$ signatures) allow insight into the trophic position of consumers. We investigated spatial and temporal changes in stable isotope signatures in salt marsh soil macrofauna of the island of Spiekeroog. The range of $\delta^{1} \llbracket N$ signatures indicated no changes in food chain length across salt marsh zones with consumers in both zones comprising primary decomposer, secondary decomposer and first order predators. However, the trophic position of individual species changed between zones, but in particular with season. Contrasting $\delta^{1} \llbracket N$ signatures, the range in $\delta^{13} \mathrm{C}$ signatures in the LSM was twice that in the USM indicating a wider range of resources consumed. Bayesian mixing models indicated predominant autochthonous resource use in both the LSM and USM, with allochthonous resource use never exceeding $29.6 \%$. However, the models also indicate an increase in the use of marine resources in certain species in the LSM with no use in the USM. Overall, the results indicate that the resource use of salt marsh macrofauna varies more in time than in space, with the food web being generally based on autochthonous rather than allochthonous resources. However, there also is trophic plasticity in certain species across both temporal and spatial scales including variations in the use of allochthonous resources. Generally, however, marine input contributes little to the nutrition of salt marsh soil macroinvertebrates.

\section{Introduction}

Ecosystems are defined by primary production and the use of those autochthonous resources by consumers such as phytophagous animals or decomposers [1, 2]. Such systems include e.g., forests and eutrophic lakes [2, 3]. By contrast, habitats such as glacier forelands, beaches and most freshwater systems are characterized by the input of external, allochthonous resources [4-6]. This input of allochthonous resources may come from far away by wind, e.g. in glacier forelands, or from adjacent habitats with greater primary productivity, e.g. marine input on beaches [4, 5, 7]. Additionally, some systems receive both allochthonous and autochthonous resources, such as salt marshes.

Salt marshes are located at the interface between marine and terrestrial systems. As a result, they are regularly flooded resulting in a vegetation zonation associated with soil accumulation [8-10]. Salt marshes fulfil several important ecosystem services, such as shoreline protection from wave action and absorption of floodwaters during storms [11]. In addition, they are among the most productive systems of the world, which is related to anoxic conditions in the soil acting as a carbon sink [11]. Furthermore, they serve as refuge for juvenile fish and migratory birds [11]. Salt marshes are inhabited by a variety of vascular plants, such as Elymus athericus (Elytrigia atherica), Atriplex portulacoides, Puccinellia maritima, Salicornia stricta and Spartina anglica, contributing to high primary productivity $[12,13]$. Additionally, tidal movements regularly flood parts of the marsh, depositing living and dead marine algae in the salt marsh [10]. In the North Sea, the tide transports large amounts of microalgae to the seashore including diatoms and dinoflagellates [14]. Both macroalgae and microalgae may flush into the marsh $[9,15]$, where they serve as resources for marine grazers occupying the lowest reaches of the marshes [16-19]. Despite this influx of marine resources to salt marshes, the relative importance of these allochthonous resources for consumers has hardly been studied.

The trophic structure of a food web determines the rate of energy fixation and transfer to higher levels in an ecosystem [20]. The trophic structure of food webs indicates its resilience to disturbances through competing species maintaining their trophic function and energy channelling [21-24]. Energy channels centre around basal resources such as primary producers or detritus $[1,23]$. Additionally, resources from adjacent systems may affect higher trophic levels through improved primary production and associated secondary production $[1,4,23]$. These energy channels may vary in time and space, similar to the use of marine resources by terrestrial detritivores in salt marsh systems, which may vary across successional stages $[13,23]$. Changes in energy channels, either through loss of a resource or addition of a new resource, influence the functional groups associated with those channels [1]. Therefore, a thorough understanding of the basal resources and the pathways they are channelled through food 
webs is vital to understand the functioning of the system. Despite this, few studies have investigated the change in basal resources across zones and the associated changes in trophic structure in Wadden Sea salt marshes.

Soil macrofauna includes species of a body size $>2 \mathrm{~mm}$ ranging from beetles to earthworms [25]. In the soil, macrofauna species are often considered ecosystem engineers because of their influence on the microbial, chemical and physical composition of the soil matrix [25-27]. Furthermore, by breaking down litter, they increase the rate of decomposition and nutrient cycling $[25,28]$. The terrestrial macrofauna living in salt marshes may benefit from both autochthonous vascular plants and allochthonous algal or marine litter. This benefit may induce greater consumer production, thus influencing trophic structure [4]. Past studies of salt marsh succession by Bakker et al. (2015) as well as Schrama et al. (2013) suggest a decline in the use of marine resources with declining inundation frequency as a result of shore height. Trophic interactions, such as consumption of larval instars of rove beetles by the carabid beetle Dicheirotrichus gustavii [29] as well as consumption of algal wrack by the talitrid amphipod Talitrus saltator on the beaches of barrier islands [4,30], have been identified. While studying trophic interactions by direct observations is difficult due to the small size of the soil fauna and their prey, and the inaccessibility of their habitat, past studies have suggested that specialists are rare [26,31]. Given the increased availability of marine resources in the lower reaches of the salt marsh and the generalist feeding nature of soil decomposers, it is likely that these allochthonous resources are exploited influencing the trophic structure and nutrient availability in the marsh. For studying the trophic structure of animal communities natural variations in stable isotope ratios $\left({ }^{15} \mathrm{~N} /{ }^{14} \mathrm{~N},{ }^{13} \mathrm{C} /{ }^{12} \mathrm{C}\right)$ are increasingly used and this also applies to salt marshes [10]. Previous studies in the salt marsh of the North Sea using stable isotopes in fact indicated increased use of marine resources by oribatid mites at the lowest reaches of the salt marsh [9]. However, the trophic structure of the soil macrofauna, their resource-use and changes across salt marsh zones and seasons have not been investigated.

Given the regular flooding of the marshes and the small size of consumers and prey, delineating the trophic structure of salt marsh food webs using direct observations of trophic interactions is virtually impossible. However, studies based on stable isotopes allowed insight into the diet and trophic position of benthic macrofauna and mesofauna of salt marshes [9, 32, 33]. Stable isotope analysis allows determining trophic levels through ${ }^{1} \varangle \mathrm{N} /{ }^{14} \mathrm{~N}$ ratios as well as identification of the resources used through ${ }^{13} \mathrm{C} /{ }^{12} \mathrm{C}$ ratios [34]. ${ }^{1} \mathbb{N}$ concentrations increase with transfer to higher trophic levels, thus allowing to estimate the trophic level of consumers $[34,35] .{ }^{13} \mathrm{C}$ concentration, on the other hand, varies between resources, specifically plants with differing photosynthetic pathways (C3 and C4) $[34,35]$ allowing to trace the channelling of these resources through food webs. Both of these isotopes have been used in intertidal salt marshes to understand changes in the quality of organic matter with time [36]. In addition, they have been used to delineate marine resource use by insect larvae consumed by spiders on shorelines of the Baltic Sea [37] as well as by Polychaeta, Pulmonata and Amphipoda of coastal waters $[33,38]$. $\delta^{13} \mathrm{C}$ signatures become especially useful when investigating the use of marine and terrestrial resources due to the distinct $\delta{ }^{13} \mathrm{C}$ signatures of algae $[9,23,33]$. Differences in $\delta^{13} \mathrm{C}$ signatures between algae and other plants are due to algae using bicarbonate as inorganic carbon source resulting in enriched $\delta^{13} \mathrm{C}$ signatures, which may also vary with light and nutrient availability [39-41]. Therefore, using $\delta^{13} \mathrm{C}$ and $\delta^{15} \mathrm{~N}$ signatures may allow discerning the use of allochthonous marine and autochthonous terrestrial plant resources as well as the trophic structure of salt marsh soil macrofauna.

Here, we investigated the importance of allochthonous marine input (mainly algae) compared to autochthonous terrestrial resources for the soil macrofauna of the upper (USM) and lower salt marsh (LSM). Furthermore, we compared the trophic structure of the salt marsh soil macrofauna across salt marsh zones as well as seasons. More specifically, we investigated the following hypotheses: (1) The consumption of allochthonous marine algal resources increases with greater tidal influence i.e., the enrichment of ${ }^{13} \mathrm{C}$ in consumers of the LSM is higher than in consumers of the USM. (2) Resembling terrestrial habitats, salt marsh soil macrofauna communities consist of four trophic levels including primary decomposers, secondary decomposers, first order predators and second order predators [26]. (3) Resource use of soil macrofauna varies across seasons (spring, summer, autumn) and zone with allochthonous marine resources being especially important for the salt marsh macrofauna food web in autumn due to heavy storms carrying large amounts of marine resources to higher positions in the salt marsh.

\section{Materials And Methods Study site}


Sampling was performed in the Wadden Sea salt marsh of Spiekeroog, Lower Saxony, Germany, as part of the DynaCom project (https://uol.de/en/icbm/collaborative-projects/dynacom). The Wadden Sea stretches across the Netherlands to Denmark and holds a vast area of salt marshes and mudflats [42]. Two types of marshes exist, the "back-barrier" and "foreland" salt marshes [8]. Back-barrier marshes form on the leeward side of barrier islands, thus are sheltered from strong wave action [8]. Due to the lack of strong wave action, sediment is deposited and over time a gradient of shore height is formed $[8,10]$. This gradient alters the inundation period and frequency, resulting in different vegetation zones. The USM is located $35 \mathrm{~cm}$ or more above the mean high-water level, with inundations occurring up to 70 times a year, whereas the LSM lies between 0-35 cm above the mean highwater level and is flooded up to 250 times a year $[43,44]$.

\section{Sampling}

Sampling was performed on the 16th of April (spring), 16th of July (summer) and 22nd of October 2019 (autumn) during low tide along five transects $\left(53^{\circ} 45^{\prime} 2^{\prime \prime}-53^{\circ} 47^{\prime} 1^{\prime \prime} \mathrm{N}, 7^{\circ} 40^{\prime} 0^{\prime \prime}-7^{\circ} 49^{\prime} 1^{\prime \prime} \mathrm{E}\right)$. Per transect and zone one soil core ( $\varnothing 20 \mathrm{~cm}$, depth $\left.10 \mathrm{~cm}\right)$ was taken. Animals were extracted by heat [43] and stored in $70 \%$ thanol at $-20^{\circ} \mathrm{C}$. Animals were determined to group or species level [44]. Additionally, litter, soil, vascular plant species and macroalgae were collected and stored at $-20^{\circ} \mathrm{C}$ (Supplementary table 2).

\section{Sample preparation and stable isotope analysis}

Samples were dried at $60^{\circ} \mathrm{C}$ for $24 \mathrm{~h}$ and weighed into tin capsules using a fine scale (Cubis MSE 3.6P, Sartorius). Variations in stable isotope ratios $\left({ }^{13} \mathrm{C} /{ }^{12} \mathrm{C}\right.$ and ${ }^{1} \mathbb{V N} /{ }^{14} \mathrm{~N}$ ) were measured by an elemental analyser (Euro EA 3000, EuroVector S.p.A; Milano Italy) modified for small samples coupled with an isotope mass spectrometer (Delta V Plus, Thermo Electron, Bremen Germany) [45]. Ratios of stable isotopes were expressed as $\delta X(\%)=\left[\left(R_{\text {sample }}-R_{\text {standard }}\right) / R_{\text {standard }}\right] \times 1000$, with ' $X$ ' representing the target isotope and ' $R$ ' the heavy-to-light isotope ratios $\left({ }^{13} \mathrm{C} /{ }^{12} \mathrm{C}\right.$ and $\left.{ }^{1} \square \mathrm{N} /{ }^{14} \mathrm{~N}\right)$ of the sample and standard, respectively. Vienna PD Belemnite (PDB) was used as standard for $\delta^{13} \mathrm{C}$ and atmospheric nitrogen for $\delta^{1} \mathbb{} \mathrm{N}$. Acetanilide was used for internal calibration.

\section{Statistical analysis}

Signatures of $\delta^{1} \varangle \mathrm{N}$ and $\delta^{13} \mathrm{C}$ of macrofauna taxa were analysed using linear mixed effects models with "Zone" and "Season" as fixed factors and "Core ID" nested within "Transect" as random factor. Due to inconsistent occurrence across zone and season, macrofauna taxa were analysed separately. The full factorial model with Zone and Season could only be fitted for T. saltator, Ochthebius/Asiobates dilatatus and D. gustavii present in both zones and all three seasons, except for D. gustavii which was not found in the USM in April. Staphylinidae larvae (April, July and October) and chalcidoid wasps (July and October) were only found in the LSM, and therefore only season was fitted as fixed factor. Similarly, in Amischa spp. only season was fitted as fixed factor as it was only found in the USM (April, July and October). In cores where two or more species occurred, the ranges in ${ }^{13} \mathrm{C}$ and ${ }^{1} \square \mathrm{N}$ signatures of the species were calculated (most ${ }^{13} \mathrm{C}$ or ${ }^{1} \square \mathrm{N}$ enriched - least ${ }^{13} \mathrm{C}$ or ${ }^{1} \square \mathrm{N}$ enriched) and analysed using MANOVA in Statistica 13 (TIBCO Software Inc. 2018; http://tibco.com). To determine the dependence of species on autochthonous and allochthonous resources, Bayesian mixing models were calculated per season using FRUITS (Beta Version 2.1.1) using fractionation factors for ${ }^{1} \square \mathrm{N}$ and ${ }^{13} \mathrm{C}$ of $3.5 \%$ ond $4.0 \%$, respectively. The fractionation factors are well established; for ${ }^{13} \mathrm{C}$ the fractionation factor is based on the 'detrital shift' as described in Potapov et al. (2019) and reflects the relative enrichment of soil animals compared to litter. Because of lack of replicates across season for Dyschirius sp. Argenna sp. and Linyphiidae, mixing models analysing variations in stable isotope signatures in these species / taxa were only fitted with Zone as fixed factor. The vegetation at both zones was dominated by C3 plants and the mean signatures of algae and vascular plant species were used in the mixing models (Supplementary table 1). The C4 plant Spartina anglica, present at the transition to the mudflats, was not included in the pool of potential resources as animal signatures indicated that it did not form part of the basal resources. To determine changes in the isotope range of animal species / taxa with Zone and Season, the range of ${ }^{1} \mathbb{Q N}$ and ${ }^{13} \mathrm{C}$ signatures of animal species / taxa per plot was used.

\section{Results}

In total, six macrofauna species, 20 plant species (Supplementary table 2) as well as soil and litter were collected and analysed for $\delta^{13} \mathrm{C}$ and $\delta^{1} \varangle \mathrm{N}$ signatures. In April, animal $\delta^{13} \mathrm{C}$ signatures ranged from -21.63 to $-25.93 \%$ ond $\delta^{1} \varangle \mathrm{N}$ signatures from 5.02 to $13.97 \%$, respective ranges in July were -22.50 to -25.65 for $\delta^{13} \mathrm{C}$ and 5.05 to $18.93 \%$ o for $\delta^{1} \mathbb{N}$, and in October -22.83 to 
$-26.19 \%$ o for $\delta^{13} \mathrm{C}$ and 4.10 to $14.79 \%$ o for $\delta^{1} \llbracket \mathrm{N}$ (Fig. 1). Respective ranges of terrestrial vascular plants for $\delta^{13} \mathrm{C}$ and $\delta^{1} \llbracket \mathrm{N}$ were 27.15 to $-26.44 \%$ ond 4.01 to $10.44 \%$ in April, -27.61 to $-24.44 \%$ ond 5.32 to $9.08 \%$ o in July, and -28.62 to $-25.72 \%$ o and 4.43 to $8.42 \%$ in October (Fig. 1).

\section{Salt marsh zones}

Among individual taxa $\delta^{1} \mathbb{\mathrm { N }}$ signatures between the LSM and USM were significant in 0 . dilatatus $(7.81 \pm 0.69 \%$ and $4.68 \pm$ $0.70 \%$, respectively) and $T$. saltator $(9.54 \pm 0.95 \%$ ond $6.70 \pm 0.82$, respectively) (Table 1$)$. Further, $\delta^{13} \mathrm{C}$ signatures of 0 . dilatatus were significantly higher in the LSM than the USM (-22.69 $\pm 0.45 \%$ ond $-23.65 \pm 0.41 \%$, respectively), whereas in $D$. gustavii $\delta^{13} \mathrm{C}$ signatures in the LSM were significantly lower than in the USM $(-25.92 \pm 0.35 \%$ ond $-24.73 \pm 0.40 \%$, respectively $)$ (Table 1).

Table 1

F- and p-values of linear mixed-effects model on variations in $\delta^{1} \llbracket N$ and $\delta^{13} \mathrm{C}$ signatures of macrofauna taxa with season (April, July, October) and salt marsh zone (upper salt marsh, lower salt marsh) on the island of Spiekeroog in 2019; ' $n$ ' number of replicates; "' not significant, * $p<0.05, * \star p<0.01, * \star * p<0.001 ; N / A$, not analysed.

\begin{tabular}{|c|c|c|c|c|c|c|c|c|c|c|c|c|c|}
\hline \multirow[t]{3}{*}{ Species } & \multirow[t]{3}{*}{$\mathrm{n}$} & \multicolumn{4}{|c|}{ Zone (Z) } & \multicolumn{4}{|c|}{ Season (S) } & \multicolumn{4}{|l|}{$Z \times S$} \\
\hline & & \multicolumn{2}{|l|}{$\mathbb{D}^{1} \mathbb{\Delta N}$} & \multicolumn{2}{|l|}{$\nabla^{13} \mathrm{C}$} & \multicolumn{2}{|l|}{$\nabla^{1} \mathbb{N N}$} & \multicolumn{2}{|l|}{$\nabla^{13} \mathrm{C}$} & \multicolumn{2}{|l|}{$\mathbb{Q}^{1} \mathbb{\Delta N}$} & \multicolumn{2}{|l|}{$\nabla^{13} \mathrm{C}$} \\
\hline & & $F$ & $p$ & $\mathbf{F}$ & $\mathrm{p}$ & $F$ & $p$ & $\mathbf{F}$ & p & $F$ & $p$ & $\mathbf{F}$ & p \\
\hline $\begin{array}{l}\text { Talitrus } \\
\text { saltator }\end{array}$ & 15 & 26,19 & 0,004 & 2,40 & 0,156 & 10,76 & 0,019 & 1,23 & 0,336 & 0,53 & 0,620 & 1,71 & 0,235 \\
\hline $\begin{array}{l}\text { Ochthebius } \\
\text { dilatata }\end{array}$ & 16 & 61,01 & 0,001 & 7,73 & 0,003 & 7,47 & 0,039 & 1,55 & 0,269 & 1,05 & 0,426 & 7,84 & 0,013 \\
\hline $\begin{array}{l}\text { Dicheirotrichus } \\
\text { gustavii }\end{array}$ & 10 & 9,22 & 0,075 & 37,44 & 0,001 & 9,85 & 0,021 & 8,97 & 0,024 & 4,95 & 0,069 & 0,06 & 0,819 \\
\hline Chalcid wasps & 6 & \multirow{2}{*}{\multicolumn{2}{|c|}{ Only LSM }} & & & 11,19 & 0,075 & 0,95 & 0,384 & \multirow[t]{3}{*}{ N/A } & & & \\
\hline $\begin{array}{l}\text { Staphylinidae } \\
\text { larvae }\end{array}$ & 7 & & & & & 10,99 & 0,015 & 2,64 & 0,275 & & & & \\
\hline Amischa spp. & 9 & \multicolumn{2}{|c|}{ Only USM } & & & 0,41 & 0,705 & 27,33 & 0,030 & & & & \\
\hline
\end{tabular}

\section{Trophic levels}

Typically, the communities spanned three trophic levels, including primary decomposers, secondary decomposers and first order

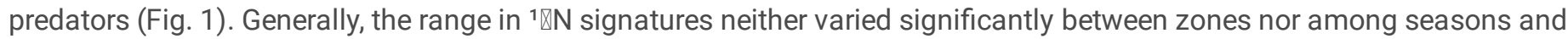
averaged $5.18 \pm 0.26 \%$ o in the USM and $6.21 \pm 1.42 \%$ o in the LSM. By contrast, the range in ${ }^{13} \mathrm{C}$ signatures varied significantly with Zone, with $0.91 \pm 0.40 \%$ in the USM and $2.67 \pm 0.43 \%$ in the $L S M(F \mathbb{Q}, \mathbb{Q}=15.26, p=0.001)$, but not with Season. In addition, in the USM T. saltator changed its trophic level from secondary decomposer in April and October to primary decomposer in July (Fig. 1a, c, e). Furthermore, in the USM Amischa sp. changed its trophic level from secondary decomposer in April to first order predator in October.

\section{Season}

Among individual species, $\delta^{1} \llbracket \mathrm{N}$ signatures only varied significantly with season in D. gustavii, O. dilatatus, Staphylinidae larvae and T. saltator (Table 1). In D. gustavii $\delta^{1} \varangle \mathrm{N}$ signatures were significantly higher in October $(12.89 \pm 0.64 \%$ o) than in July (11.89 \pm $1.02 \%$ o), whereas in 0 . dilatatus they increased significantly from April $(5.95 \pm 1.32 \%$ o) to July $(7.06 \pm 1.96 \%$ o $)$ and decreased

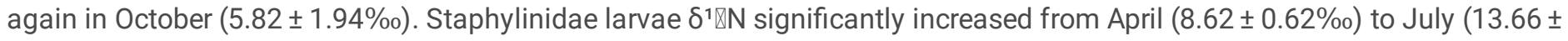
$2.15 \%$ ) and remained stable in October $\left(12.36 \pm 1.18 \%\right.$ o). In T. saltator $\delta^{1} \otimes \mathrm{N}$ declined from April $(9.09 \pm 1.61 \%$ ) to July $(7.20 \pm$ $1.28 \%$ o and remained stable in October $\left(7.79 \pm 1.38 \%\right.$ o). $\delta^{13} \mathrm{C}$ signatures varied significantly with season in $D$. gustavii and Amischa sp. Furthermore, in $O$. dilatatus the effect of Season depended on Zone (Table 1). In D. gustavii $\delta^{13} \mathrm{C}$ signatures significantly decreased from July $\left(-25.16 \pm 0.65 \%\right.$ ) to October $\left(-25.73 \pm 0.75 \%\right.$ ). For Amischa $\mathrm{sp} . \delta^{13} \mathrm{C}$ signature increased from 
April $(-24.05 \pm 1.04 \%$ o $)$ to July $\left(-23.97 \pm 1.32 \%\right.$ o) and declined again in October $\left(-24.52 \pm 1.01 \%\right.$ o). By contrast, in 0 . dilatatus $\otimes^{13} \mathrm{C}$ signatures changed little with Season in the USM $(-23.95 \pm 0.46,-23.51 \pm 0.01 \%$ ond $-23.46 \pm 0.42 \%$ o for April, July and October, respectively), whereas in the LSM $\otimes^{13} \mathrm{C}$ signatures gradually declined from April $(-22.19 \pm 0.12 \%$ o) to July $(-22.57 \pm 0.14 \%$ o $)$ to October $(-23.14 \pm 0.32 \%)$.

\section{Allochthonous resource use}

Bayesian mixing models indicated an almost exclusive use of terrestrial resources across taxa in both the LSM and USM. In April they used $85-98 \%$ terrestrial resources with the exception of Argenna sp. in the LSM (70.4 $\pm 17.8 \%)$ (Fig. 2a); in July they used 90-97\% terrestrial resources with the exception of the chalcidoid wasps of the LSM (74.4 $\pm 17.3 \%$ ) (Fig. 2b). In October they used 83-97\% terrestrial resources with the exception of Staphylinidae larvae in the LSM (75.6 $\pm 16.2 \%)$ (Fig. 2c).

\section{Discussion}

We investigated the trophic structure and allochthonous resource use of the soil macrofauna of the Wadden Sea salt marsh. Consisting of only three trophic levels the macrofauna food web is simpler than the previously investigated mesofauna food web (Haynert et al. 2017). Stable isotope signatures varied significantly between salt marsh zones and seasons, with a significant interaction between Zone and Season for $O$. dilatatus. Further, in the LSM the range of $\delta^{13} \mathrm{C}$ signatures significant increased later in the year. However, as indicated by Bayesian mixing models, allochthonous marine resources generally are of little importance for the nutrition of soil macrofauna in both the LSM and USM.

\section{Differences between salt marsh zones}

Stable isotope signatures of soil macrofauna species / taxa differed significantly between the USM and LSM confirming our first hypothesis. $\delta^{1} \otimes \mathrm{N}$ signatures were generally higher in the LSM compared to the USM and this applied in particular to 0 . dilatatus and $T$. saltator as well as in trend to $D$. gustavii. Only $\delta^{13} \mathrm{C}$ signatures varied significantly between salt marsh zones in $D$. gustavii, with higher enrichment in the USM than the LSM. Higher $\delta^{1} \mathbb{N}$ signatures in macrofauna species / taxa in the LSM than in the USM contrast patterns in salt marsh mesofauna, in which $\delta^{1} \mathbb{N N}$ signatures were higher in the USM than in the LSM (Haynert et al. 2017). Haynert et al. (2017) suggested this pattern to indicate longer food chains in the USM, which we did not find in our study. Considering the higher $\delta^{1} \mathbb{N}$ signatures of soil, plant and litter material in the LSM than the USM, the higher signatures of $O$. dilatatus and T. saltator in the LSM than in the USM are likely related to higher enrichment of basal resources, pointing to the

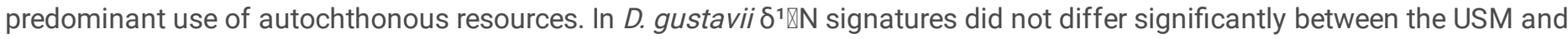
LSM. However, in the USM D. gustavii occupied a higher trophic position than in the LSM. Furthermore, in the LSM D. gustavii was significantly less enriched in ${ }^{13} \mathrm{C}$ compared to the USM. Predation on algal-feeding rove beetle larvae of Bledius spectabilis may explain the trophic position of $D$. gustavii in the $\operatorname{LSM}[29,46]$. Algae rely on atmospheric $N$ and are generally considered to be depleted in ${ }^{1} \varangle \mathrm{N}$ (Potapov et al. 2019). However, the low $\delta^{13} \mathrm{C}$ signatures of $D$. gustavii in the LSM suggests no consumption of marine resources. Instead, as discussed in Potapov et.al (2019), low $\delta^{13} \mathrm{C}$ and high $\delta^{1} \otimes \mathrm{N}$ signatures indicates the consumption of resources based on freshly fixed carbon or consumers thereof, again pointing to the dominant use of autochthonous resources.

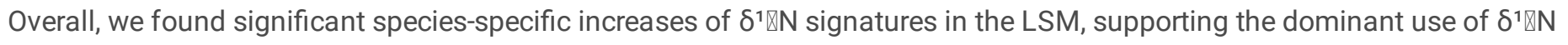
enriched autochthonous resources in the LSM. Enrichment in ${ }^{13} \mathrm{C}$ in $D$. gustavii in the LSM also points to the use of autochthonous C3 plant resources.

\section{Trophic level}

Regardless of season or zone, macrofauna communities consisted of three trophic levels rejecting our second hypothesis. The results suggest that the salt marsh macrofauna food web uniformly comprises primary decomposers, secondary decomposers and first order predators. The latter included chalcidoid wasps (Chalcidoidea) parasitizing a wide range of host species [47]. These findings are in contrast to Haynert et al. (2017) reporting four trophic levels for the salt marsh soil mesofauna. The lower number of trophic levels in macrofauna across both zones is likely due to high disturbance by inundation reducing soil macrofauna diversity. As proposed by the intermediate disturbance hypothesis, we expected a reduction in diversity with disturbance frequency [48]. However, while inundation frequency indeed is lower in the USM than in the LSM, soil salinity is high 
in both the USM and LSM $[49,50]$. As discussed by Connell (1978) increased abiotic stressors may reduce diversity and favour the dominance of specialists. Contrasting these assumptions, the wider range in $\delta^{13} \mathrm{C}$ signatures of macrofauna species in the LSM compared to the USM points to more flexible resource use in species of the former, presumably due to increased use of surface microalgae [12]. Overall, the results suggest that the salt marsh soil macrofauna food web is simpler than expected, presumably due to frequent flooding and associated disturbances resulting in the dominance of tolerant specialists increasing their resource spectrum in particular in the LSM.

\section{Season}

Although seasonal variations in stable isotope signatures generally were less pronounced than variations between salt marsh zones, $\delta^{1} \otimes \mathrm{N}$ signatures varied significantly with season in D. gustavii, O. dilatatus, Staphylinidae larvae and T. saltator. Further, $\delta^{13} \mathrm{C}$ signatures varied significantly in $D$. gustavii, Amischa sp. and $O$. dilatatus, but in the latter this depended on salt marsh zone confirming our third hypothesis. $\delta^{1} \mathbb{N}$ signatures in D. gustavii of the USM changed considerably with season indicating a switch from living as secondary decomposer in April to living as predator in October, whereas in the LSM D. gustavii constantly lived as secondary decomposer. Changes in resource use in $D$. gustavii in the USM is supported by the decline in $\delta^{13} \mathrm{C}$ signatures from July to October indicating a switch from herbivore prey in July to decomposer prey in October (cf. Potapov et al. 2019). In 0. dilatatus, $\delta^{1} \mathbb{N}$ signatures in the LSM, but not the USM, were higher in July than in April and October. Further, $\delta^{13} \mathrm{C}$ signatures in the LSM declined later in the year, indicating increased use of autochthonous terrestrial resources. Previous studies showed Ochthebius species to scrape mats of microalgae on rocky shores as well as to feed on detritus (Beier and Pomeisl 1959, Perkins 1980). In the salt marsh Ochthebius species occur in or near saline channels, with larval stages living submerged [54-56] suggesting that they consume resources of marine origin. Contrasting this assumption, our results based on Bayesian mixing models indicate that the resources used by $O$. dilatatus in salt marshes are primarily based on autochthonous vascular plant litter material. $\delta^{1} \varangle \mathrm{N}$ of LSM Staphylinidae larvae point to a trophic change from primary decomposer in April, to secondary decomposer in July and October. These changes could point to increased consumption of partially decomposed litter, or the direct consumption of primary decomposer by later larval stages. Variations in $\delta^{1} \mathbb{\otimes N}$ signatures with season in T. saltator indicate trophic plasticity in this species in particular in the USM, where its trophic position changed from secondary decomposer in April to primary decomposer in July and back to secondary decomposer in October. Direct feeding on plant litter might be related to increased plant growth and litter production during summer. Overall, variations in $\delta^{1} \otimes \mathbf{N}$ signatures in $T$. saltator suggests that in salt marshes this species lives as opportunistic omnivore with its diet including microorganisms but also plant litter material depending on resource availability. This contrasts previous studies at beaches suggesting that $T$. saltator predominantly feeds on algae [7]. In Amischa sp. from the USM, $\delta^{13} \mathrm{C}$ signatures declined significantly in October, which may point to increased predation on herbivores, whereas in April and July they may feed more on decomposer prey (cf. Potapov et al. 2019). Overall, resource use of a number of salt marsh macrofauna species changed with season indicating trophic plasticity. However, this was restricted to few species suggesting that resources vary little between seasons.

\section{Allochthonous resource use}

As indicated by Bayesian mixing models the salt marsh macrofauna almost exclusively exploits autochthonous C3 plant resources with the use of allochthonous marine resources being restricted to few species and not exceeding $29.6 \%$, contradicting our third hypothesis. Species feeding predominantly on terrestrial resources regardless of season included D. gustavii, Amischa sp. and $T$. saltator. In the carabid beetle D. gustavii this suggests predation on phytophagous species. By contrast, Amischa sp. likely fed on both animal prey as well as fungi as Aleocharinae rove beetles are known to function as both detritivores and predators [57]. As indicated by their $\delta^{1} \llbracket \mathrm{N}$ signatures, in the salt marsh they predominantly function as detritivores of terrestrial C3 plant-based resources, only occasionally feeding on animal prey. Unexpectedly, T. saltator also exclusively relied on terrestrial resources (see above), with its variable trophic position indicating that in salt marshes it lives as omnivore. On the other hand, the spider Argenna sp., Staphylinidae larvae and chalcidoid wasps indicated some marine resource use at least at certain sampling dates. In April, the use of marine resources was highest in Argenna sp. in the LSM, presumably due to feeding on dipterans with marine larval stages (Hambäck et al. 2016). In Staphylinidae larvae the use of marine resources in the LSM was highest in October; in chalcidoid wasps in April and July. These resource changes may be related to higher flooding frequency at those time periods and the associated increase in marine detritus. Staphylinidae larvae may either use fungi in the deposited detritus or prey on detritivores such as dipteran larvae. Similarly, increased use of marine resources in chalcidoid wasps, might be due to

Page $7 / 14$ 
parasitizing dipteran larvae developing in deposited marine detritus as has been shown for seaweed flies on beaches [58]. Overall, the results suggest that allochthonous input of marine resources is of limited importance for the salt marsh macrofauna community regardless of season and zone.

\section{Conclusions}

We investigated the trophic structure, trophic plasticity and resource use of the salt marsh macrofauna along spatial and temporal scales. Compared to the soil mesofauna and typical terrestrial habitats, the trophic structure of the salt marsh macrofauna is more simple with only three trophic levels irrespective of zone and season, presumably reflecting disturbance frequency and harsh abiotic conditions resulting in less diverse communities comprising predominantly habitat specialists. $\delta^{13} \mathrm{C}$ signatures and Bayesian mixing models indicated that the macrofauna community relies on autochthonous C3 plant-based resources, regardless of season and zone. Changes in resource use were species-specific with the use of allochthonous marinebased resources being restricted to chalcidoid wasps, the spider Argenna sp. and Staphylinidae larvae. Generally, variations in stable isotope ratios suggest that spatial variation in trophic niches exceeds seasonal variation. Overall, the trophic structure of the salt marsh macrofauna is rather simple, similar to arable systems, with terrestrial C3 plants as the main resource and allochthonous marine material being of little importance.

\section{Declarations}

\section{Ethics approval and consent to participate}

Not applicable

\section{Consent for publication}

Not applicable

\section{Availability of data and materials}

The datasets generated and/or analysed during the current study are available in the DRYAD repository (doi:10.5061/dryad.tdz08kq1t), https://datadryad.org/stash/share/sCK5KbHOxJzZgmCQsrYkdtJiZhH10igspyu2800HBzk

\section{Competing interests}

The authors declare that they have no competing interests in this study.

\section{Relevant guidelines and regulations}

All research methods performed in this study complied with the permission granted to the DynaCom research project for 2019 under §21 article 1 of the NWattNPG from the Wadden Sea National Park of Lower Saxony (Germany).

\section{Funding}

This study was funded by the German Research Foundation (DFG) in the framework of the 'DynaCom' project - project number 379417748 (FOR 2716).

\section{Authors' contributions}

Experimental design: Maria Rinke, Mark Maraun \& Stefan Scheu

Sample collection: Maria Rinke, Philipp M. Bendisch

Selection of taxa: Maria Rinke

Stable isotope preparation: Philipp M. Bendisch 
Data checks: Maria Rinke, Mark Maraun

Statistical approach: Maria Rinke, Mark Maraun \& Stefan Scheu

Data analysis: Maria Rinke

Figure preparation: Maria Rinke

First manuscript: Maria Rinke

Manuscript review/edits: All authors

\section{Acknowledgements}

We thank the Wadden Sea National Park of Lower Saxony, Germany for permission to take samples as well as the Wittbülten Nationalpark-Haus for their accommodation and support during fieldwork. We also thank Barbara Wozniak for help during sampling and preparation of specimens for stable isotope analysis. Further, we thank Susanne Böhning-Klein for support in sample preparation for stable isotope analysis, and Reinhard Langel and the staff of the Stable Isotope Unit (KOSI) of the University of Göttingen for help with stable isotope measurements.

\section{Authors' information}

University of Göttingen, J.F. Blumenbach Institute of Zoology and Anthropology, Animal Ecology, Untere Karspüle 2, 37073 Göttingen, Germany - Maria Rinke, Philipp Marvin-Bendisch, Mark Maraun and Stefan Scheu

University of Göttingen, Centre of Biodiversity and Sustainable Land Use, Büsgenweg 1, 37077 Göttingen, Germany - Stefan Scheu

Maria Rinke Orcid 0000-0002-8781-8002 - maria.rinke@uni-goettingen.de

Philipp M. Bendisch - p.bendisch@stud.uni-goettingen.de

Mark Maraun Orcid 0000-0002-2736-8548 - mmaraun@gwdg.de

Stefan Scheu - Orcid 0000-0003-4350-9520 sscheu@gwdg.de

\section{References}

1. Chapin FS, Matson PA, Vitousek PM. Principles of Terrestrial Ecosystem Ecology. Second edi. New York: Springer, New York, NY; 2011.

2. Lau DCP, Sundh I, Vrede T, Pickova J, Goedkoop W. Autochthonous resources are the main driver of consumer production in dystrophic boreal lakes. Ecology. 2014;95:1506-19.

3. Gower ST, Krankina O, Olson RJ, Apps M, Linder S, Wang C. Net primary production and carbon allocation patterns of boreal forest ecosystems. Ecological Applications. 2001;11:1395-411.

4. Lastra M, Page HM, Dugan JE, Hubbard DM, Rodil IF. Processing of allochthonous macrophyte subsidies by sandy beach consumers: Estimates of feeding rates and impacts on food resources. Marine Biology. 2008;154:163-74.

5. Ingimarsdóttir M, Michelsen A, Ripa J, Hedlund K. Food sources of early colonising arthropods: The importance of allochthonous input. Pedobiologia. 2014;57:21-6.

6. Neres-Lima V, Machado-Silva F, Baptista DF, Oliveira RBS, Andrade PM, Oliveira AF, et al. Allochthonous and autochthonous carbon flows in food webs of tropical forest streams. Freshwater Biology. 2017;62:1012-23.

7. Adin R, Riera P. Preferential food source utilization among stranded macroalgae by Talitrus saltator (Amphipod, Talitridae): A stable isotopes study in the northern coast of Brittany (France). Estuarine, Coastal and Shelf Science. 2003;56:91-8. 
8. Bakker JP, Nielsen KJ, Alberti J, Chan F, Hacker SD, Iribarne OO, et al. Bottom-up and top-down interactions in coastal interface systems. In: Trophic Ecology: Bottom-Up and Top-Down Interactions Across Aquatic and Terrestrial Systems. 2015. p. 157-200.

9. Winter M, Haynert K, Scheu S, Maraun M. Seasonal dynamics and changing sea level as determinants of the community and trophic structure of oribatid mites in a salt marsh of the Wadden Sea. PLoS ONE. 2018;13:1-18.

10. Haynert K, Kiggen M, Klarner B, Maraun M, Scheu S. The structure of salt marsh soil mesofauna food webs - The prevalence of disturbance. PLoS ONE. 2017;12:1-20.

11. Barbier EB, Hacker SD, Kennedy C, Koch EW, Stier AC, Silliman BR. The value of estuarine and coastal ecosystem services. Ecological Monographs. 2011;81:169-93.

12. Bouchard V, Creach V, Lefeuvre JC, Bertru G, Mariotti A. Fate of plant detritus in a European salt marsh dominated by Atriplex portulacoides (L.) Aellen. Hydrobiologia. 1998;373/374:75-87.

13. Bakker JP, de Leeuw J, Dijkema KS, Leendertse PC, Prins HHT, Rozema J. Salt marshes along the coast of The Netherlands. Hydrobiologia. 1993;265:73-95.

14. Hoppenrath M. A revised checklist of planktonic diatoms and dinoflagellates from Helgoland (North Sea, German Bight). Helgoland Marine Research. 2004;58:243-51.

15. Riera P, Stal LJ, Nieuwenhuize J, Richard P, Blanchard G, Gentil F. Determination of food sources for benthic invertebrates in a salt marsh (Aiguillon Bay, France) by carbon and nitrogen stable isotopes: Importance of locally produced sources. Marine Ecology Progress Series. 1999;187:301-7.

16. Sullivan M, Moncreiff C. Edaphic algae are an important component of salt marsh food-webs: evidence from multiple stable isotope analyses. Marine Ecology Progress Series. 1990;62:149-59.

17. Andresen M, Kristensen $\mathrm{E}$. The importance of bacteria and microalgae in the diet of the deposit-feeding polychaete Arenicola marina. Ophelia. 2002;56:179-96.

18. Araújo CVM, Moreira-Santos M, Patrício J, Martins I, Moreno-Garrido I, Blasco J, et al. Feeding niche preference of the mudsnail Peringia ulvae. Marine and Freshwater Research. 2015;66:573-81.

19. Heijden LH Van Der, Graeve M, Asmus R, Rzeznik-orignac J, Niquil N, Bernier Q. Trophic importance of microphytobenthos and bacteria to meiofauna in soft- bottom intertidal habitats: A combined trophic marker approach. Marine Environmental Research. 2019;149 January:50-66.

20. Hairston NG. Cause-effect relationships in energy flow, trophic structure, and interspecific interactions. The American Naturalist. 1993;142:379-411.

21. Leibold MA, Chase JM, Shurin JB, Downing AL. Species turnover and the regulation of trophic structure. Annual Review of Ecology and Systematics. 1997;28:467-94.

22. Rooney N, McCann KS, Moore JC. A landscape theory for food web architecture. Ecology Letters. 2008;11:867-81.

23. Schrama M, Jouta J, Berg MP, Olff H. Food Web Assembly at the Landscape Scale: Using Stable Isotopes to Reveal Changes in Trophic Structure During Succession. Ecosystems. 2013;16:627-38.

24. Hussey NE, Macneil MA, Mcmeans BC, Olin JA, Dudley SFJ, Cliff G, et al. Rescaling the trophic structure of marine food webs. Ecology Letters. 2014;17:239-50.

25. Coleman DC, Crossley JA, Hendrix PF. Fundamentals of Soil Ecology. Second Edition. Academic Press; 2004.

26. Scheu S, Ruess L, Bonkowski M. Interactions Between Microorganisms and Soil Micro- and Mesofauna. Microorganisms in Soils: Roles in Genesis and Functions. 2005;3:253-75.

27. Bottinelli N, Jouquet P, Capowiez Y, Podwojewski P, Grimaldi M, Peng X. Why is the influence of soil macrofauna on soil structure only considered by soil ecologists? Soil and Tillage Research. 2015;146:118-24.

28. Riutta T, Slade EM, Bebber DP, Taylor ME, Malhi Y, Riordan P, et al. Experimental evidence for the interacting effects of forest edge, moisture and soil macrofauna on leaf litter decomposition. Soil Biology and Biochemistry. 2012;49:124-31.

29. Wyatt TD, Foster WA. Leaving home: predation and the dispersal of larvae from the maternal burrow of Bledius spectabilis, a subsocial intertidal beetle. Animal Behaviour. 1989;38:778-85. 
30. Dauby P, Khomsi A, Bouquegneau JM. Trophic relationships within intertidal communities of the Brittany Coasts: A stable carbon isotope analysis. Journal of Coastal Research. 1998;14:1202-12.

31. Digel C, Curtsdotter A, Riede J, Klarner B, Brose U. Unravelling the complex structure of forest soil food webs: higher omnivory and more trophic levels. Oikos. 2014;123:1157-72.

32. Galois R, Richard P, Fricourt B. Seasonal variations in suspended particulate matter in the Marennes- Oleron Bay, France, using lipids as biomarkers. Estuarine, Coastal and Shelf Science. 1996;43:335-57.

33. Créach V, Schricke MT, Bertru G, Mariotti A. Stable Isotopes and Gut Analyses to Determine Feeding Relationships in Saltmarsh Macroconsumers. Estuarine, Coastal and Shelf Science. 1997;44:599-611.

34. Traugott M, Kamenova S, Ruess L, Seeber J, Plantegenest M. Empirically Characterising Trophic Networks: What Emerging DNA-Based Methods, Stable Isotope and Fatty Acid Analyses Can Offer. In: Advances in Ecological Research. 1 st edition. Elsevier Ltd.; 2013. p. 177-224.

35. Layman CA, Post DM. Can stable isotope ratios provide for community-wide measures of trophic structure? Ecology. 2008;89:2358-9.

36. Spohn M, Babka B, Giani L. Changes in soil organic matter quality during sea-influenced marsh soil development at the north sea coast. Catena. 2013;107:110-7.

37. Hambäck PA, Weingartner E, Dalén L, Wirta H, Roslin T. Spatial subsidies in spider diets vary with shoreline structure: Complementary evidence from molecular diet analysis and stable isotopes. Ecology and Evolution. 2016;6:8431-9.

38. Lange G, Haynert K, Dinter T, Scheu S, Kröncke I. Adaptation of benthic invertebrates to food sources along marine-terrestrial boundaries as indicated by carbon and nitrogen stable isotopes. Journal of Sea Research. 2018;131:12-21.

39. Hecky RE, Hesslein RH. Contributions of benthic algae to lake food webs as revealed by stable isotope analysis. Journal of the North American Benthological Society. 1995;14:631-53.

40. Dudley B, Barr N, Shima J. Influence of light intensity and nutrient source on $\delta 13 \mathrm{C}$ and $\delta 15 \mathrm{~N}$ signatures in Ulva pertusa. Aquatic Biology. 2010;9:85-93.

41. Spalding MH. Photosynthesis and photorespiration in freshwater green algae. Aquatic Botany. 1989;34:181-209.

42. Flemming B, Jr Davis AR. Holocene evolution, morphodynamics and sedimentology of the Spiekeroog barrier island system(southern North Sea). Senckenbergiana maritima. Frankfurt/Main. 1994;24:117-55.

43. Kempson D, Lloyd M, Ghelardi R. A new extractor for woodland litter. Pedobiologia. 1963;:1-30.

44. Schaefer M. Brohmer, Fauna von Deutschland: ein Bestimmungsbuch unserer heimischen Tierwelt. 25th edition. Quelle \& Meyer; 2018.

45. Langel R, Dyckmans J. Combined $13 \mathrm{C}$ and $15 \mathrm{~N}$ isotope analysis on small samples using a near-conventional elemental analyzer/isotope ratio mass spectrometer setup. Rapid Communications in Mass Spectrometry. 2014;28:1019-22.

46. Wyatt TD. How a subsocial intertidal beetle, Bledius spectabilis, prevents flooding and anoxia in its burrow. Behavioral Ecology and Sociobiology. 1986;19:323-31.

47. Abraham R. Ökologische Untersuchungen an Pteromaliden (Hym., Chalcidoidea) im Grenzraum Land-Meer an der Nordseeküste Schleswig-Holsteins. Oecologia (Berl). 1970;6:15-47.

48. Connell JH. Diversity in tropical rain forests and coral reefs. Science. 1978;199:1302-10.

49. Meier D, Thölen C, Hillebrand H, Kleyer M, Lohmus K, Zielinski O. Continuous wave and tide observations at DynaCom artificial islands in the back-barrier tidal flat, Spiekeroog, Germany, 2019-01 to 2019-12. Pangaea. 2020. https://doi.pangaea.de/10.1594/PANGAEA.918521. Accessed 24 Aug 2021.

50. Meier D, Thölen C, Lohmus K, Hillebrand H, Zielinski O, kleyer M. Pore-water salinity measurements in surface sediments (2019) within DynaCom experimental islands and saltmarsh enclosed plots at different elevation levels, Spiekeroog, Germany, 2019-01 to 2019-10. PANGAEA. 2020. https://doi.pangaea.de/10.1594/PANGAEA.915460. Accessed 24 Aug 2021.

51. Potapov AM, Tiunov A v., Scheu S. Uncovering trophic positions and food resources of soil animals using bulk natural stable isotope composition. Biological Reviews. 2019;94:37-59. 
52. Beier M, Pomeisl E. Einiges über Körperbau und Lebensweise von Ochthebius exsculptus germ. und seiner Larve (Col. Hydroph. Hydraen). Ökologie der Tiere. 1959;48:72-88.

53. Perkins, D. P. Aquatic beetles of the family Hydraenidae in the western hemisphere: Classification, biogeography and inferred phylogeny (Insecta : Coleoptera). Quaestationes Entomologicae. 1980;16:1-554.

54. Healy B. Fauna of the Salt-Marsh, North Bull Island, Dublin. Proceedings of the Royal Irish Academy. Section B: Biological, Geological, and Chemical Science. 1975;75:225-44.

55. Meyer H, Fock H, Haase A, Reinke HD, Tulowitzki I. Structure of the invertebrate fauna in salt marshes of the Wadden Sea coast of Schleswig-Holstein influenced by sheep-grazing. Helgoländer Meeresuntersuchungen. 1995;49:563-89.

56. Ruta R, Stachowiak M, Aleksandrowicz O. The first record of Paracymus aeneus (GERMAR, 1824) (Coleoptera: Hydrophilidae) in Poland with notes on halophilous and halobiontic Hydrophilidae and Hydraenidae in Polish fauna. Polish Journal of Entomology / Polskie Pismo Entomologiczne. 2006;75:359-68.

57. Thayer MK. 14.7 Staphylinidae Latreille 1802. In: Beutel RG, Leschen RAB, editors. Coleoptera, Beetles. Morphology and Systematics. Berlin; 2005. p. 294-345.

58. Notton GG. Diapriid wasps (Hym., Proctotrupoidea) from Abbots Moss, Cheshire. Lancashire \& Cheshire Fauna Society. 1996;:23-4.

\section{Figures}



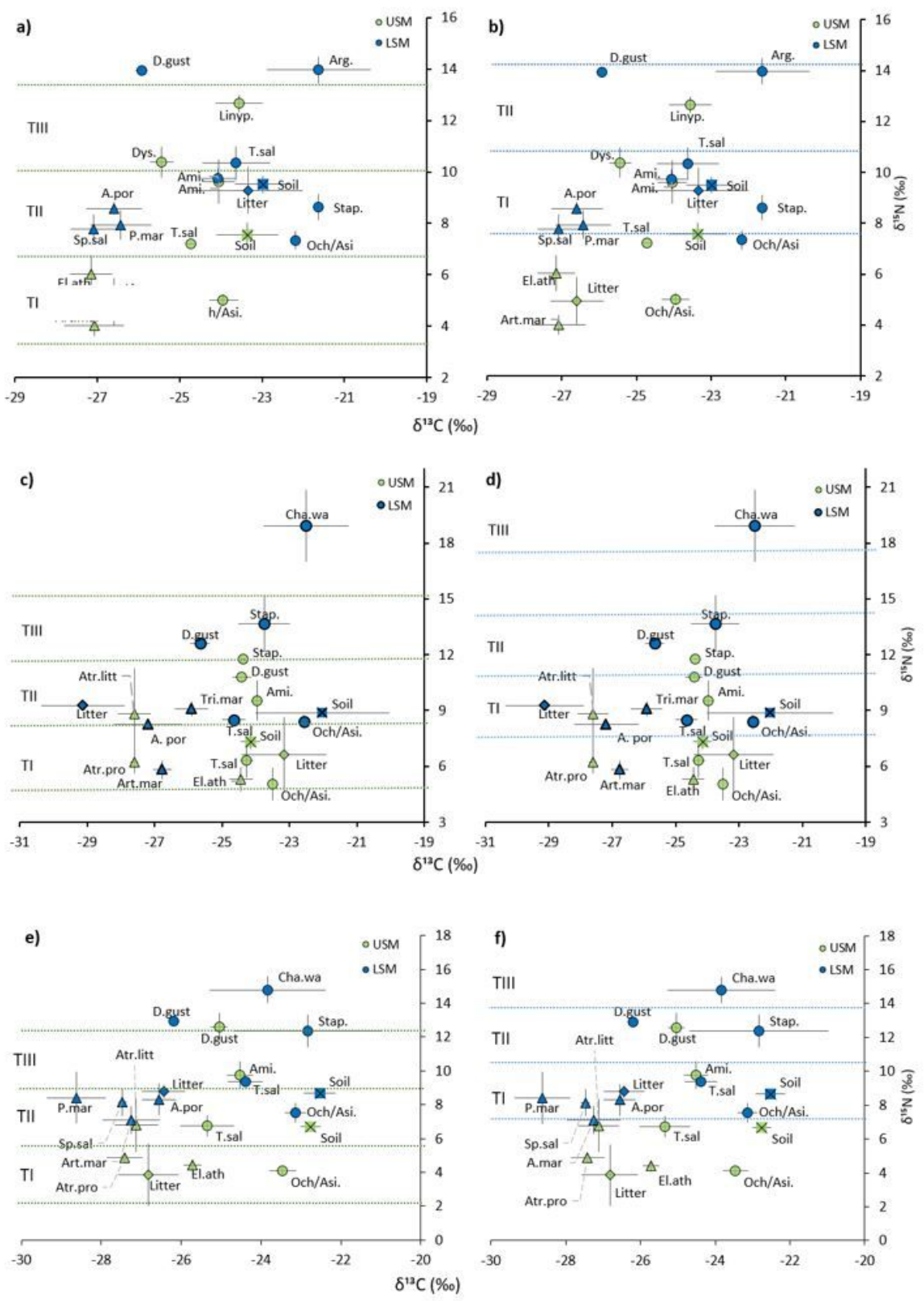

\section{Figure 1}

Scatterplot of $\delta 15 \mathrm{~N}$ und $\delta 13 \mathrm{C}$ signatures of salt marsh fauna species / taxa (circles), plants (triangles), litter (diamonds) and soil (crossed squares) in the (a) USM in April, (b) LSM in April, (c) USM in July, (d) LSM in July, (e) USM in October and (f) LSM in October; means \pm SD; green = upper salt marsh (USM), blue= lower salt marsh (LSM). Dotted lines indicate trophic levels. Animals: Ami. - Amischa sp., Arg. - Argenna sp., D.gust - Dicheirotrichus gustavii, Dys. - Dyschirius sp., Ochth. - Ochthebius dilatatus, Linyp. - Linyphiidae, Stap. - Staphylinidae larvae, T.sal - Talitrus saltator. Plants: Atr.litt - Atriplex littoralis, Art.mar Artemisia maritima, A.por - Atriplex portulacoides, Atr.pro - Atriplex prostrata, El.ath - Elymus athericus, P.mar- Puccinellia maritima, Sp.sal - Spergularia salina. 

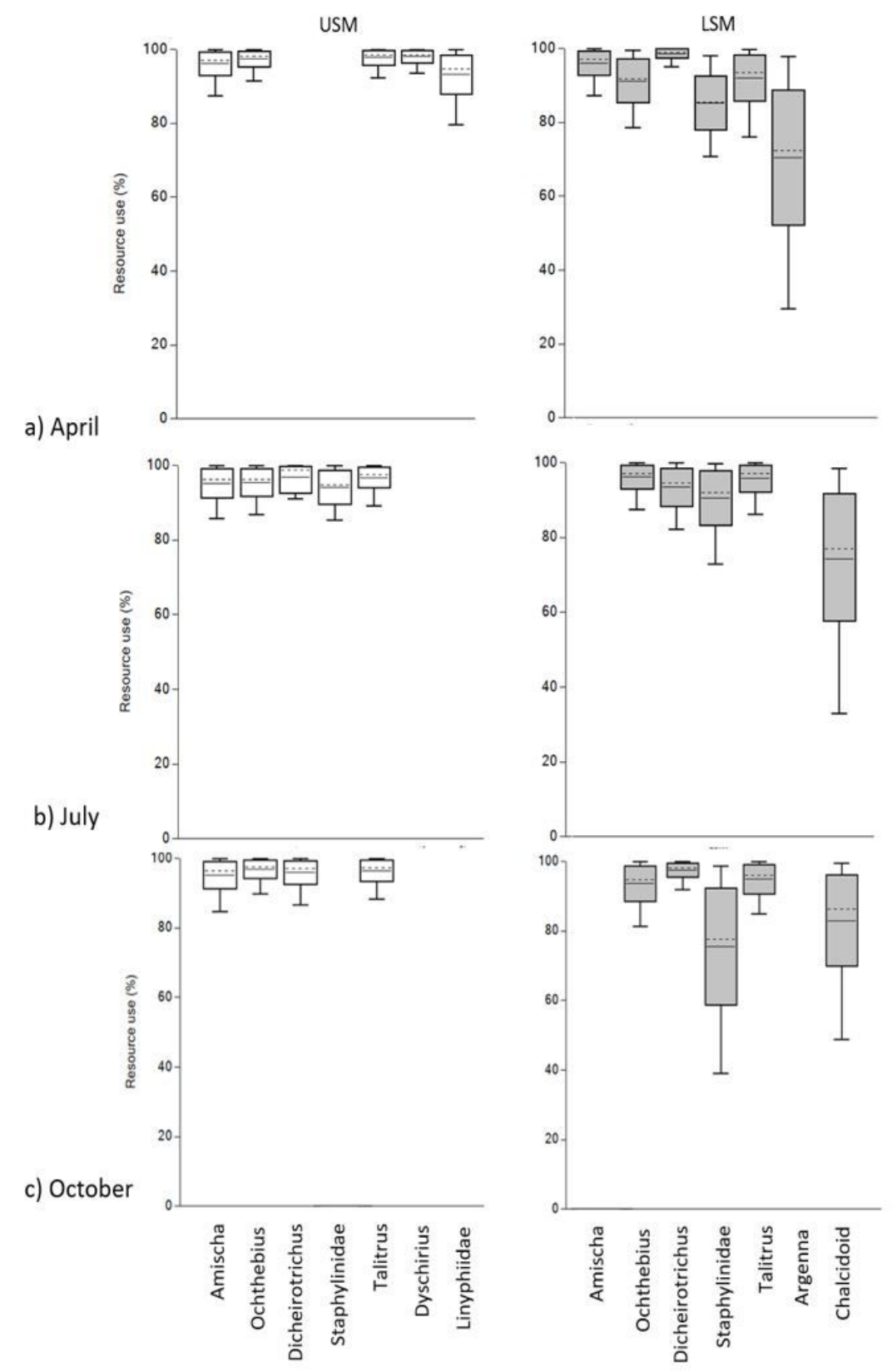

\section{Figure 2}

Boxplot of results of Bayesian mixing models on the use of terrestrial vs marine resources (\%) by macrofauna species in the salt marsh of Spiekeroog in (a) April, (b) July and (c) October. Left panel (white boxes) = upper salt marsh (USM), right panel (grey boxes) $=$ lower salt marsh (LSM). Boxes represent the $68 \%$ confidence intervals, error bars $95 \%$ confidence intervals; the solid horizontal line represents the mean, the dashed horizontal line the median.

\section{Supplementary Files}

This is a list of supplementary files associated with this preprint. Click to download.

- Supplementaryfile.xlsx

- Supplementaryinfo.xlsx 